Proceedings of the Second Annual Forestry Symposium 1996: Management and Sustainable Utilization of Forest Resources, Sri Lanka, 6-7 December 1996. (Eds. Amarasekera, HS, Ranasinghe, D MS HK and Finlayson, W. Published by Department of Forestry and Environmental Science, University of Sri Jayewardenepura, Sri Lanka (1998)

\title{
FLORISTIC RICHNESS AND RECREATION POTENTIAL OF POMPEKELLE FOREST RESERVE
}

\author{
W.S.K. Pathirathne', D.M.S.H.K. Ranasinghe ${ }^{1}$ and K. Deheragoda ${ }^{2}$ \\ 'Department of Forestry and Environmental Science. University of Sri Jayewardenepura \\ 'Department of Geography, University of Sri Jayewardenepura
}

\begin{abstract}
Pompekelle Forest Reserve is a small urban forest in the heart of Ratnapura town in the lowlands. of southwestern Sri Lanka. In a phytoecological survev, woody plants of more than $5 \mathrm{~cm}$ dbh were enumerated in samples of the hilltop. mid-slope and valley. Species richness, diversity, evenness, dominance and importance-value indices were calculated. A total of 116 species were found, belonging to 38 families. Species diversity and evenness were higher on the hilltop than in the valley. Species dominance was higher in the vallev than on the hilltop and mid-slope. Trees of the Apocvnaceae, Celastraceac, Dilleniaceae, Leguminosae, and Moraceae were prominent throughout. Separate communities were identified for the hilltop, mid-slope and vallev. Endemicity was higher on the hilltop than on the mid-slope and in the valley. There was an abundance of regenerating canopy species, which indicates that the forest is fast recovering from past interference such as illicit felling. A longterm recreational development plan was prepared on the basis of the floristic data obtained in the present survey, a questionnaire survey with about 200 respondents, and a resource survey that used aerial photographs and "oneinch" maps. It was supplemented with a working plan that included detailed site drawings
\end{abstract}

\section{Introduction}

Ecotourism has become a very attractive use option in developing countries that have tropical forests. The growing demand presents numcrous opportunitics for increasing sustainable local and national development, while at the same time protecting national parks and reserves so that the tropical forest and other cultural heritages remain intact. Promotion of tourism in these reserves may help to promotc local pride and cultural awareness. while it also generates an income for the local population. However, this type of development requires cooperation by the public and private sectors of the economy (including the local people themselves) as well as adequate funding, planning, and innovative training, for the proper recognition of ecotourism. 
Ecotourism may have undesirable cconomic, cultural and socio-economic effects if it is not practiced with great care. In a review of the cconomic analysis of ecotourism Steele (1995) expressed apprehension about how open access to renewable natural sites may lead to both economic and environmental inefficiency. He stressed the importance of strong ownership for the successful imple-mentation of ecotourism. In a study of protected areas and nature conservation on and near Iriomete Island, in Japan, Tisdell \& Takashi (1992) claimed that the enforcement of conservation regulations appeared to be hampered. in both protected land and marine areas, by the lack of available government staff for surveillance: there had been continuing problems in reconciling increasing tourism with nature conservation. In an extensive study of the potentials and pitfalls of ccotourism in Belize, Costa Rica and Dominica, Boo (1990) reported that negative environmental impacts on the forest reserves had been minimal. However. as obstacles to the success of ecotourism. he picked out poor transport and accommodation infrastructure in the parks, inadequate promotion, lack of a park service. and lack of trained guides to give nature tours.

The main objective of the present study was to assist in the planning being done by the Ratnapura Municipal Council. by providing information on various ecological characteristics of the forest (floristic richness. diversity, endemism) and to prepare a plan for developing its recreational potential.

\section{Study site}

Pompekelle belongs to the category of forests collectively known as "Other State Forests", which individually are Icss than 200 ha in the dry zone or 20 ha in the wet zone, and are managed by the Local Administration. It is about 12 ha in cxtent, situated in the heart of Ratnapura town. and is administered by the Ratnapura Municipal Council. Prior to its being declared the Pompekelle Urban Forest Park. it had become a degraded patch of forest under the negative influence of human activities. It is now in the process of being developed for educational and recreational purposes by the Municipal Council, with the help and guidance of the Forest Department and other government agencies. There are about 86,000 people living in the area that comes under the Municipal Council. Some families live very close to, and even inside the forest. It used to be the catchment area for the reservoir located inside it, which supplied water to the town. However, the reservoir has now been abandoned because of siltation and pollution by human activity.

Because of its location in the wet lowlands of Sri Lanka, the vegetation is related to that of the other low-country wet evergreen forests. The mean annual rainfall is $3749 \mathrm{~mm}$, with more than 206 rainy days per year, and the mean annual temperature is $27.5^{\circ}$.

\section{Phytosociological survey}

\section{Size and shape of plots}

Fixed-area plots were used, as this sampling method yields data such as a species list, and estimates of stem density, frequency, diameter-class distribution, basal area and 
abundance. All woody plants with a dbh of more than $5 \mathrm{~cm}$ were enumerated in plots of $20 \times 20 \mathrm{~m}$. Within these large plots, smaller plots of $5 \times 5 \mathrm{~m}$ were set out, in which saplings ( $<5 \mathrm{~cm} \mathrm{dbh}$ and $>1 \mathrm{~m}$ in height) were enumerated. Within the $5 \times 5 \mathrm{~m}$ plots. 1 $\times 1 \mathrm{~m}$ plots were laid out in which seedlings (woody plants $<1 \mathrm{~m}$ in height) were cnumerated. For trees, a record was made of the number of species, number of individual trees, dbh, and height, For saplings and seedlings, only the numbers of species and of individuals were recorded. Herbarium specimens were prepared for plants unidentified in the field.

\section{Number of plots sampled}

In order to detcrmine the number of plots to be sampled, the number of new species encountered in each new plot was plotted against the number of plots sampled. The point at which such a curve, projected, is going to intersect the horizontal axis gives an estimate of how many plots should be sampled.

\section{Stand variables}

The relative density of each species and the stem number density of each plot were calculated from the data collected. The basal area of each species for stems $>5 \mathrm{~cm}$ dbh were calculated within each plot.

\section{Ecological indices}

Shannon's ecological indices of diversity, evenness. and dominance were calculated for each plot by the following formulas:

Diversity: $\quad \mathrm{H}^{\prime}=\mathrm{Pi} \times \log (\mathrm{Pi})$

where $\mathrm{Pi}$ is proportional abundance

Evenness: $\quad J^{\prime}=\mathrm{H}^{\prime} / \mathrm{H}^{\prime} \max$

where $H^{\prime} \max =\log \mathrm{S}$, and $\mathrm{S}$ is the number of species

Dominance: $\quad 1-\mathrm{J}^{\prime}$

Importance value index $($ IVI $)=$ Relative density + Relative basal area + Relative frequency

Relative density $=$ number of individuals of a species $\div$ total number of all individuals

Relative basal area $=$ total basal area of a species $\div$ total basal area of all species

Relative frequency $=$ frequency of one species $\div$ total frequency of all species 


\section{Results}

A total of 23 plots were sampled, each with an area of $400 \mathrm{~m}^{2}$. Of these, 8 were on the hilltop. 8 on the mid-slope and 7 in the valley. Table 1 shows the numbers of new species found in these plots in each area.

Table 1: Distribution of sample plots by site type, and the number of new species found in each plot

\begin{tabular}{cccccc}
\hline & Hillop & \multicolumn{3}{c}{ Mid-slope } & Valley \\
\hline $\begin{array}{c}\text { Plot } \\
\text { No. }\end{array}$ & $\begin{array}{c}\text { No. of new } \\
\text { species }\end{array}$ & Plot No. & $\begin{array}{c}\text { No. of new } \\
\text { species }\end{array}$ & Plot No. & $\begin{array}{c}\text { No. of new } \\
\text { species }\end{array}$ \\
1 & 11 & 2 & 16 & 5 & 14 \\
4 & 9 & 3 & 11 & 6 & 16 \\
7 & 12 & 8 & 6 & 11 & 5 \\
9 & 8 & 10 & 5 & 14 & 0 \\
12 & 0 & 13 & 4 & 19 & 4 \\
16 & 5 & 15 & 2 & 20 & 5 \\
22 & 3 & 17 & 4 & 21 & 2 \\
23 & 2 & 18 & 0 & & \\
\hline
\end{tabular}

In all. 116 species were cnumerated, belonging to 80 genera and 36 families; 36 were endemic species, belonging to 34 families. The hilltop showed the greatest floristic richness. diversity and evenness. followed by the mid-slope and the valley. The valley showed the greatest species dominance. The percentage endemicity was greatest on the litltop. followed by the mid-slope and valley (Tables 2 and 3 ).

Table 2 : Floristic composition by site type

\begin{tabular}{lccc}
\hline & Hiltop & Mid-slope & Valley \\
\hline Number of plots & 6 & 8 & 7 \\
Total number of species & 49 & 41 & 44 \\
Total number of individual plants & 134 & 198 & 144 \\
Endemics as a percentage of the & 56 & 45 & 39 \\
lotal number of individual plants & & & \\
\hline
\end{tabular}

Table 3 : Average values of Shannon's indices of diversity, evenness and dominance by site types

\begin{tabular}{lccc}
\multicolumn{1}{c}{ Elevation } & Diversity & Evenness & Dominance \\
\hline Hilltop & 0.175 & 0.168 & 0.832 \\
Mid-slope & 0.020 & 0.060 & 0.816 \\
Valley & 0.010 & 0.043 & 0.957 \\
\hline
\end{tabular}

Trees belonging to the families Apocynaceae, Cclastraceae, Dilleniaccae. Leguminosae, and Moraceae were prominent throughout the forest. There were 13 dominant tree species (based on IVl values): Alstonia macrophylla, Anisophylla cinnamomoides, 
Alstonia scholaris, Artocarpus heterophvllus, Bhesa zevlanica, Dillenia sulffuticosa, (iarcinia quasita, Hedyotis fruticosa, Horsficeldia iriva. Humboldtia lourifolia, Kokoona zevlanica, Myristica dactyloides, and Santhophylum geminiflorum. A complete list of the woody flora is given in an Appendix. The following tree communities were recognized on the hilltop and mid-slope:

Hilltop:

Canopy: Vitex-Dillenia-Shorea-Mangifera

Understorey: Semecarpus mooni-Dillenia, with saplings and scedlings of dominant and canopy trees

Mid-slope:

Canopy: Dillenia-( haetocarpus-Alstonia-Myristica

Understorey: Schumacheria -Hamboldtia-(iarcima Dillenia-Syzvgium, with saplings and seedlings of canopy trees

The reduced foristic composition and diversity in the valley indicate that of the three areas it has been most subjected to human interference. The presence of a reservoir with public access could have made this worse. Although many references can be found in a series of papers by Gunatilleke \& Gunatilleke (sec for cxample Gunatillcke \& Gunatilleke. 1985) to the presence of Mesua, Doona, Dipterocarpus, and Shorea species in the low-country wet-zone forests. they are almost non-existent in this forest: perhaps they have been selcctively exploited in the past. Upon comparing the floristic richness of Pompekclle with six other lowland wet-zone forests, as reported by Gunatilleke \& Gumatilleke (1985) it was apparent that although percentage endemicity was less, the numbers of species. genera and families in Pompekelle were comparable to those of the other lowland wet-zone forests.

The presence of pioneer genera, such as Dillenia, Alstonia, and Schumacheria, supplies further evidence that the forest had been extensively disturbed by human activities. The greatest number of stems sampled were in the $10-20 \mathrm{~cm}$ dbh class, and there were few trees of greater $\mathrm{dbl}$. This finding also indicates that the forest is still regenerating. and fast recovering from human disturbance.

\section{Survey of recreational potential}

\section{Data gathering}

A questionnaire survcy was conducted among about 200 people, including school children, teachers, businessmen, government workers. and others who live in and around Ratnapura. They were selected randomly, as individuals. Aerial photographs and ground survey maps were used to evaluate forest cover and to locate the boundary of the forest reserve. The existing resources were marked on the maps. This work was supplemented with field observations of the forest. The observations of the phytosociological survey were also utilized.

A working map was prepared from the existing maps and the data. It shows the the type of developmental activities proposed, the sites where they will be located, the time

\section{0}


needed for development, and any recognizable problems. Detailed drawings were prepared for each activity proposed.

\section{Results and discussion}

It was apparent that the reserve had already been used for activities such as hiking. picnicking. nature watching, swimming. etc., although at a low intensity. After it was made into an urban forest park its use by children from schools in and around Ratnapura greatly increased. Almost all the respondents to the questionnaire survey, sclected randomly from a cross section of people with diverse backgrounds, agreed that more recreational facilities should be provided. This shows the enhanced awareness of the general public in the appreciation of nature.

It is proposed to include the following activities in the forest reserve in the future. Figure I shows their location in the reserve. Because of the limited funds available, it is proposed that devclopment should be in three stages according to priority:

Initial stage. Construction of more nature trails, more picnic benches. summer huts, a research centre. toilets, a car park. camping facilities, a room for a permanent guard. rehabilitation of the reservoir, trails for bird and butterfly watching. labelling the trees along the trails with both botanical and local names, introducing a demonstration medicinal garden, planting the disturbed areas with native trees. planting bamboos and ornamental trees in the valley. It is proposed to introduce a guide service to assist visitors, as a lack of trained guides to give nature tours has been found elsewhere to be an obstacle to successful ecolourism (Boo, 1990).

Sécond stage. Building a lodging facility and a snack bar. The need for these depends on the attraction of visitors to the site which in turn depends greatly on the amount of publicity given to the forest park. Therefore, it was proposed to give increased publicity to the forest by way of electronic and print media, leaflets, signboards by the roadside, and other promotional activities. All the infrastructure building will be done in the disturbed area. The hilltop will be made the least accessible part as there is greater species richness and diversity compared with the other sites, and from the ecological point of view it is the most worth protecting.

In order to gencrate funds for the effective maintenance of the forest park it is proposed to introduce an appropriate entry fee. It has been observed by many researchers that an entry fee does not deter tourists from visiting, if they think the forest is worth a visit (Tobias et al. 1991: Maille et al., 1993).

However promising the introduction of recreation facilities may seem, negative cnvironmental impacts could occur. They may include littering. cutting trees for camp fires. making huts. etc., and disturbance with damaging effects on the behaviour and ccology of resident wildlife. Observations on these effects have been reported by 
Whelan, 1979; Griffiths et al,, 1993. Lippold, 1990). Fines should be imposed to deter these malpractices. Assignment of a guard to overlook the entire forest and to make sure that all activities go according to plan is strongly recommended.

\section{References}

Boo. E. (1990). Belize, ('osta Rica, Dominica, ecotourism: the potentials and pitfalls. Baltimore. USA, World Wildlife Fund.

Griffiths, M.. Schaik. C.P. and Van Schaik, C.P. (1993). The impact of human traffic on the abun-dance and activity periods of Sumatran rainforest wildlife. Conservation Biology 7 (3) 623-626.

Gunatilleke. C.V.S. and Gunatilleke. I.A.U.N. (1985). Phytosociology of Sinharaja - a contribution to rain forest conservation in Sri Lanka. Biological (onservation $31,21-40$.

Maille. P. and Mendelsohn, R. (1993). Ecotourism in Madagascar's tropical biological reserves. Journal of Environmental Management 38 (3) 213-218.

Lippold, L.K. (1990), Primate population decline at Cabo Blanco Absolute Nature Reserve, Costa Rica. Bremesia 34. 145-152.

Steele. P. (1995). Ecotourism, an cconomic analysis. Journal of Sustainahle Tourism 3. $29-44$

Tisdell, C.A. and Takahashi, S. (1992). Protected areas and nature conservation on and near Irimote Island. Japan. Tigerpaper 19 (4) 1-7.

Tobias, D. and Mendelsohn. R. (1991). Valuing ecotourism in a tropical rainforest reserve. Ambio 20 (2) 91-93.

Whelan, T. (1979). Nature tourism management for the envirionment. Sri Lanka Forester $11(1 / 2)$.

\begin{tabular}{lll} 
Appendix - The floristic composition of Pompekelle (woody plants $>\mathbf{5} \mathbf{~ c m ~} \mathbf{d h h}$ ) \\
\hline Family & \multicolumn{1}{c}{ Scientific name } & \multicolumn{1}{c}{ Local name } \\
Anacardiaceae & Semecarpus mooni & badulla \\
& Mangifera zevlanica & elamba \\
& Campnosperma zeylanica & aridda \\
& Mangifera indica & amba \\
Annonaceae & Artabotrys zeylanicum & yakada wel \\
& Aylopia parvifolia & netaw \\
& Uvaria merum & bu pattika \\
& Uvaria zeylanicum & palukan \\
& Polyalthia saberosa & kalati \\
Apocynaceae & Plumeria acuminata & araliya \\
& Alstonia macrophylla & hawarinuga \\
& Alstonia scholaris & rukaththana \\
& Pagiantha zeylanica & divikaduru \\
Burseraceae & Canarium zeylanicum & kakuna \\
Celastraceae & Bhesa zeylanica & pelanga
\end{tabular}


Pathirathne, Ranasinghe and Deheragoda

\begin{tabular}{|c|c|c|}
\hline & Kokoona zeylanica & kokoon \\
\hline \multirow[t]{4}{*}{ Clusiaccae } & (iarcinia quasita & rath goraka \\
\hline & Garcinia echinocarpa & madol \\
\hline & Callophyllum thwaitesii & keena \\
\hline & Mesua nagasarium & na \\
\hline Commaraccae & ('ommarus championii & radalia wel \\
\hline Convolvulaceace & Argvreia populifolia & girithilla wel \\
\hline \multirow[t]{5}{*}{ Dilleniaceae } & Dillenia suffruticosa & malpara \\
\hline & Tetracera sarmentosa & corasa wel \\
\hline & Wormia triquetra & diyapara \\
\hline & Schumacheria castanaeifolia & kekiriwera \\
\hline & Dillenia retusa & godapara \\
\hline \multirow[t]{2}{*}{ Dipterocarpaceae } & Shorea trapezifolia & yakahalu dun \\
\hline & Shorea congestiflora & tiniya dun \\
\hline Ebenaceae & Diospyros insignis & \\
\hline Elacocarpaceac & Elacocarpus seratus & weralu \\
\hline \multirow[t]{5}{*}{ Euphorbiaceac } & Chaetocarpus castanaeocarpus & hadawaka \\
\hline & Bridelia mooni & patkela \\
\hline & Macaranga peltata & kanda \\
\hline & Brevnia rhamnoides & gas kela \\
\hline & Aporosa lanceolata & heenkirilla \\
\hline \multirow[t]{4}{*}{ Lauraccac } & Neolitsea cassia & davulkunundu \\
\hline & Litsea longifolia & ratkeliya \\
\hline & Cinnamomum multiflorum & walkurundu \\
\hline & Cryptocarya wightiana & gulumora \\
\hline \multirow[t]{6}{*}{ Leguminosac } & Enlada scandens & puswel \\
\hline & Inumboldtia lourifolia & galkaranda \\
\hline & Adenanthera aglaeosperma & masmoru \\
\hline & Aberima bigemina & kalatiya \\
\hline & Tamarindus indic:a & siyambala \\
\hline & Crotalaria retusa & keppetiya \\
\hline Liliaceae & Dracaena thwaitesii & dracaena \\
\hline \multirow[t]{3}{*}{ Melasiomaceac } & Melastoma malabarica & mabovitiya \\
\hline & Axinandra zevlanica & polhuna \\
\hline & Memecylon gardneri & pinibaru \\
\hline \multirow[t]{2}{*}{ Meliaceae } & Nelia dubia & lunumidella \\
\hline & Pseudocarpa championii & gonapana \\
\hline \multirow[t]{3}{*}{ Moraceac } & Artocarpus heterophyllus & jak \\
\hline & Artocarpus nobilis & bedidel \\
\hline & Ficus nemosa & nuga \\
\hline \multirow[t]{2}{*}{ Myristicaceac } & Myristica dactvloides & malaboda \\
\hline & Horsfieldia iriva & iriya \\
\hline \multirow[t]{4}{*}{ Myrtaceae } & Syzygium firmum & wal jambu \\
\hline & Svaygium opeculatum & batadomba \\
\hline & Syzugium caryophylatum & dail \\
\hline & Svaygium rubicundum & pinibaru \\
\hline
\end{tabular}




\begin{tabular}{|c|c|c|}
\hline Myrsinaceac & $\begin{array}{l}\text { Ardisia solanaceae } \\
\text { Apama siliquosa }\end{array}$ & $\begin{array}{l}\text { baludan } \\
\text { tapasara bulath }\end{array}$ \\
\hline Palmae & Caryota urens & kitul \\
\hline (Arecaccae) & Calamms digitatus & kukulu wel \\
\hline Polygalaceae & Xanthophyllum geminiflorum & kele gas \\
\hline Proteaceae & Grevillea robusta & sabukku \\
\hline Rhamnaceae & Ziziphus napeca & maha eraminiya \\
\hline Rhizophoraceae & $\begin{array}{l}\text { Anisophylleades } \\
\text { cinnamomoides }\end{array}$ & welipiyanna \\
\hline Rubiaccae & $\begin{array}{l}\text { Hedvotis fruticosa } \\
\text { Ixora coccinea } \\
\text { Ophiorrhiza mungos }\end{array}$ & $\begin{array}{l}\text { weraniya } \\
\text { wal rathmal } \\
\text { dathketiya }\end{array}$ \\
\hline Rutaceac & $\begin{array}{l}\text { Acronvchia pendunculata } \\
\text { Evodia lunuankenda } \\
\text { Toddalia asiatica }\end{array}$ & $\begin{array}{l}\text { ankenda } \\
\text { lunu ankenda } \\
\text { kudimirrisa }\end{array}$ \\
\hline Sapindaccac & $\begin{array}{l}\text { Harpullia arborea } \\
\text { Glemniea unijuga } \\
\text { Nephelium lappaceum } \\
\text { Filicium decipiens }\end{array}$ & $\begin{array}{l}\text { na imbul } \\
\text { malmora } \\
\text { rambutan } \\
\text { pihimbiya }\end{array}$ \\
\hline Sapotaceac & $\begin{array}{l}\text { Madhuca filva } \\
\text { Isonandra lanceolata } \\
\text { Chrusophyllum roxburghii }\end{array}$ & $\begin{array}{l}\text { wamamee } \\
\text { mol padda } \\
\text { laulu }\end{array}$ \\
\hline Smilaceae & Similax zeylanica & kabarasa wel \\
\hline Somneratiaceac & Glochidion zeylanica & kirilla \\
\hline Symplocaceae & Symplocus coccincinensis & bombu \\
\hline Ulmaceac & Trema orientalis & gadumba \\
\hline Zingiberaceac & $\begin{array}{l}\text { Tectona grandis } \\
\text { clerodendron infortunatum } \\
\text { Vitex altisimma } \\
\text { Costus speciosus }\end{array}$ & $\begin{array}{l}\text { teak } \\
\text { gas pinna } \\
\text { milla } \\
\text { thebu }\end{array}$ \\
\hline
\end{tabular}

